Western University

Scholarship@Western

Aboriginal Policy Research Consortium International (APRCi)

2001

\title{
Collapsing Australian architecture: The aboriginal tent embassy
}

Gregory Cowan

Follow this and additional works at: https://ir.lib.uwo.ca/aprci

Part of the Other Architecture Commons, and the Sociology of Culture Commons

Citation of this paper:

Cowan, Gregory, "Collapsing Australian architecture: The aboriginal tent embassy" (2001). Aboriginal Policy Research Consortium International (APRCi). 407.

https://ir.lib.uwo.ca/aprci/407 
This article was downloaded by: [University of Western Ontario]

On: 20 December 2012, At: 10:25

Publisher: Routledge

Informa Ltd Registered in England and Wales Registered Number: 1072954 Registered office: Mortimer House, 37-41 Mortimer Street, London W1T 3J H, UK

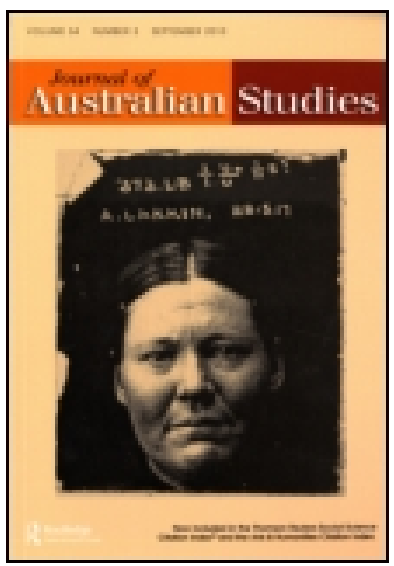

\title{
J ournal of Australian Studies
}

Publication details, including instructions for authors and subscription information: http:// www. tandfonline.com/loi/ rjau20

\section{Collapsing Australian architecture: The aboriginal tent embassy}

\author{
Gregory Cowan ${ }^{\text {a b }}$ \\ ${ }^{a}$ Teaching architecture, Curtin University, Perth \\ ${ }^{\mathrm{b}}$ Teaching architecture, Curtin University, Kuala Lumpur \\ Version of record first published: 18 May 2009.
}

To cite this article: Gregory Cowan (2001): Collapsing Australian architecture: The aboriginal tent embassy, J ournal of Australian Studies, 25:67, 30-36

To link to this article: http:// dx. doi.org/ 10.1080/ 14443050109387636

\section{PLEASE SCROLL DOWN FOR ARTICLE}

Full terms and conditions of use: http://www.tandfonline.com/page/terms-and-conditions

This article may be used for research, teaching, and private study purposes. Any substantial or systematic reproduction, redistribution, reselling, loan, sub-licensing, systematic supply, or distribution in any form to anyone is expressly forbidden.

The publisher does not give any warranty express or implied or make any representation that the contents will be complete or accurate or up to date. The accuracy of any instructions, formulae, and drug doses should be independently verified with primary sources. The publisher shall not be liable for any loss, actions, claims, proceedings, demand, or costs or damages whatsoever or howsoever caused arising directly or indirectly in connection with or arising out of the use of this material. 


\section{Collapsing Australian Architecture: the Aboriginal Tent Embassy}

\section{Gregory Cowan}

Western societies are often preoccupied with imposing hierarchical order and permanence through buildings and settlements, while nomadic societies do not generally share these concerns. It is suggested here that opportunism, ephemerality and collapsibility have affected cultures of dwelling in Australia, and that these are essential cultural qualities of architectural theories addressing the future of Australian culture. Dwelling on a moment of arrival in a new place is captured symbolically by the sudden erection of a collapsible architecture. The tent is an example of an architecture which represents an opportunistic occupation of space. It is further argued here that an uncanny similarity exists between two historical moments of illegal opportunistic camping in Australia, a recent one still evolving, and one in 1788 .

The encampment of the Aboriginal Tent Embassy began somewhat spontaneously on 26 January 1972 and continues to the present day, in the grounds of provisional Parliament House in Canberra. It has stood in protest intermittently since 1972 and permanently since 1992.' The Embassy recently sprang up at Victoria Park in South Sydney. ${ }^{2}$ A second encampment put forward here is the initial encampment of settlers of the 'First Fleet' who invaded Botany Bay intending to settle in Australia in 1788.

Pre-colonial Aboriginal architectural traditions were diverse and varied by region in building technology and socio-spatial behaviour. Tombs, hides, traps and landscape elements had greater significance as well as shelters. ${ }^{3}$ Toward the end of the twentieth century, there was increasing interest internationally in the tectonics and spatial rituals of Aboriginal architecture in Australia. Enrico Guidoni's Primitive Architecture in 1978 included a section on Aboriginal architecture ${ }^{4}$ and in 1990 Peter Blundell Jones wrote in the British Journal Architectural Review about the 'Aboriginal attitude to landscape' and 'the meaning it has in myth and ceremony'. In 1987, Bruce Chatwin's internationally successful novel The Songlines, controversial in Australia for its interpretations of Aboriginality, brought international attention to ideas of Australian nomadic reading of the 'country', as an alternative spatial definition of 'architecture'. 6 Australian architecture and landscape are cultural interests which warrant close scholarly attention in regard to the processes of reconciliation in Australia:

\section{Invasion of Canberra}

On the 26 January 1972, four young men from Sydney erected a beach umbrella in front of Provisional Parliament House, in the Australian capital. Their protest occurred on the annual national holiday known alternatively as Invasion Day or Australia Day, the anniversary marking the original claim on the Australian continent by the British Crown. Later the same day, the land rights protest evolved into a tent 
encampment. The camp comprised a group of shelters made of a bricolage of materials, including canvas tarpaulins and plastic sheets, which could be regarded as festive. The protesters called it the Aboriginal Tent Embassy. ${ }^{7}$ The authorities however clearly regarded the form and the name of the Embassy as disturbing. ${ }^{8}$ The protesters maintained their non-violent intentions although, inspired by contemporary international politics, they occasionally broke into the violent rhetoric of the Australian 'Black Panther Movement'.' International debate in the media focused on the idea of an Aboriginal Tent Embassy and its political context of land rights, leading to restlessness.

The idea of an Aboriginal Tent Embassy was conceived spontaneously by the activists ${ }^{10}$ in response to statements about land rights planned for then Prime Minister McMahon's 'state of the nation' Australia Day speech, as details became known on the previous day, 25 January. According to Chicka Dixon, one of the original 'architects' of the Tent Embassy, the protest was intended to 'put our plight into the eyes of the world'."

With the capacity to appear and disappear suddenly, the Tent Embassy is ephemeral. Its constituent parts are also collapsible, organically facilitating compromise and resurrection. This Embassy is also portable, its parts being transportable in the boots of cars. These qualities made possible its dramatic removal by the Police, and also its subsequent resurrection.

\section{Invasion of Port Jackson}

On 26 January 1788, the British first fleet entered Port Jackson. This moment of transition, as the invaders approached to land in Terra Australis, is historically symbolic; it was important as a moment of tension, during which the fleet remained poised in the harbour. Their celebration of the evening of 26 January consisted of anchoring the ships, christening the town site, and firing four volleys of small arms. The English colours were then flown, and at the foot of the flagstaff, officers and convicts alike drank a toast to the King. ${ }^{12}$ Possession of the colony was actually not taken in form until 7 February. ${ }^{13}$

The Captain of Marines, Watkin Tench, described the encampment as:

... highly picturesque and amusing. In one place a party cutting down the woods, a second setting up a blacksmith's forge, a third dragging along a load of stones or provisions, here an officer pitching his marquee, with a detachment of troops parading on one side of him, and a cook's fire blazing up on the other.

Tench went on to record that after these chaotic beginnings of the 1788 Port Jackson encampment, a clear hierarchy was installed, however unsettled the group remained:

Through the unwearied diligence of those at the head of the different departments, regularity was, however, soon introduced and, as far as the unsettled state of matters would allow, confusion gave place to system. ${ }^{14}$

On 27 January, Ralph Clark, second lieutenant of marines, arriving after months at sea, wrote a letter to his wife: 
I am much charmed with the place. Oh that if you was only here and our dear boy, my Alicia, I should not wish to come home ... The tents look pretty among the trees. I hope to be on shore tomorrow. ${ }^{15}$

The makeshift tents of the settlement were clearly considered rather inadequate by the settlers, if not disdained by the traditional landowners in their huts. There was clearly a strong desire in the colony to move to permanent buildings, especially as the weather got colder. Surgeon to the first fleet, John White later wrote of his reservations about the tents, in June 1788:

We have been here nearly six months and four officers only as yet got huts: when the rest will be provided with them seems uncertain, but this I well know, that living in tents, as the rainy season has commenced, is truly uncomfortable, and likely to give a severe trial to the strongest and most robust constitution .... ${ }^{\text {is }}$

As is evident from the joumal entry of White above, the colonists sought quickly to move on from this moment of camping in tents on Australian shores to establish permanent huts and buildings, a resemblance of what they considered to be civilisation. Yet the traditional occupants of the land were to continue to live in huts and tents for at least a further two centuries.

\section{Constructing a (White) Nation: Provisional Parliament House}

Following the federation of the Australian colonies in 1901, in the context of growing desire for a sense of Australian national identity, a national capital city was established at Canberra, following a 1912 international design competition. 'Provisional Parliament House' as it was called, was eventually built in Canberra in 1927, and was occupied by federal parliament until $1988 .{ }^{17}$

Provisional Parliament can be regarded as a piece of symbolic colonial architecture aimed at establishing an imported European cultural tradition. The building is of a generic and derivative British colonial architectural style, significantly massive and white in form, and is set in an orderly manicured lawns. It has been described by architectural historian Jennifer Taylor as a 'visually demanding white building of symmetrical design with an orderly, rhythmic distribution of its parts'. ${ }^{18}$

By 1965, Australia's provisional Parliament House was becoming too crowded. As the perceived need for a 'permanent' Parliament House grew, plans for a new Parliament House began to emerge from within the sedentary hierarchy. This was a period of increasing media awareness in Australia of the civil rights movements internationally and the Vietnam War at the end of the decade. Increasingly, it became more evident and more publicly acknowledged that racism was a significant factor in Australian politics. At about this same time, the growing sense of a pan-Aboriginal nation began to emerge from the amalgamation of state acts and the referendum of 1967 on the status of Aborigines. The referendum showed the Australian public's desire to 'include Aboriginal people in Australian Society and civil life', beginning by including their numbers in the census of the Australian population.

Since the 1930s, so-called 'Aboriginal Protection' legislation in each state and territory had restricted the movement of Aborigines. Laws such as these in states and territories forbade Aboriginal people from, for example, moving freely around 
the country without a permit and 'consorting' with non-Aborigines, and placed Aboriginal children under departmental control. Following the conference of Native Welfare Ministers in 1961, assimilation policy was gradually transformed to integration, and the acts were gradually amended or abolished in the sixties. As the new 'permanent' Australian Parliament House began to be a focus of bureaucratic governmental interest, indigenous inhabitants of Australia began to work towards forming a nation, which in the beginning of the 1970s was to be symbolised by their own flag and Embassy. The growing Aboriginal solidarity, which helped in forming a pan-Aboriginal Australian identity, also saw the advent of a more militant activism inspired by the American Black Power movement and the Indian Brotherhood movement. Provisional Parliament House stood in 1972 as an ambiguous expression of occupation. Was it a provisional parliament or a provisional 'house'? Australia appeared not yet ready to occupy a permanent Parliament House. The early seventies were to be highly significant years for the besieged architectural expression of Australian national government.

\section{Grounds for the Tent Embassy}

The most striking misinterpretation of pre-European inhabitation of Australia was reflected in the legal standard of terra nullius. For purposes of European law, it was considered that Australia before European settlement was 'practically unoccupied, without settled occupants or settled law'.19 The confusion of settlement with occupation is one which lies at the core of built environment 'ownership', and affects the limitations of what role architecture might perform in the future of Australia.

The principle of terra nullius was legally overturned in 1992, as a result of the Mabo ruling. Since that decision, the law now cautiously concedes that Australia was previously inhabited - indeed, 'practically' occupied. The Mabo and Wik decisions, in principle, have had profound significance for Australia's cultural identity and for the ongoing process of reconciling present day Australia with its past. ${ }^{20}$ Although 'practical' occupation before European settlement is now legally part of the history of dwelling in Australia, equally, the 'impractical' or 'extra-practical' the theory of a 'nomadic' architecture - remains to be reconciled with that of Western practice.

The erection of the 1972 Aboriginal Tent Embassy in the centre of Canberra was 'brilliant, audacious, imaginative, and strategic'.21 Far more than a demonstration, it was a construction, newsworthy on both Australian and international scales. ${ }^{22}$ The Embassy was and is collaboratively constructed, and is maintained as a temporal and collapsible architecture, a structure of protest. It symbolises a great deal about place making and ways of thinking about the built environment in Australia. It is also closely connected to the modern history of engendering pan-Aboriginal identity in Australia, a history which led to the formation of an Aboriginal flag and an Aboriginal nation in Australia. The Aboriginal Tent Embassy is remarkable for the ways in which it embodies what can be described as a 'nomadological' approach to architecture. This 'camp' is founded upon, firstly, an inherent ephemerality particularly in relation to the movement rituals of its erection and re-erection, transformation and maintenance.

Physically remarkable qualities of the Aboriginal Tent Embassy are its lightweight and woven structure, its capacity to be resurrected or re-erected, and 
its anti-traditional pragmatism. The lightweight and woven structure works at the level of portability, in the sense that the frames and skins of the tent surfaces can be packed up for transport by car or bus, which is the way many of the contributions to the Tent Embassy structure were brought to the site in the first place. Importantly, the 'weaving' of the Tent Embassy also has a collaborative aspect. The grouping of elements is organic, and does not follow a Western geometric pattern like a military camp. The Tent Embassy functions as an expression of its heterogeneous contributors and the mixing of spaces and materials.

Ephemerality is a quality generally associated with the 'minutiae' of existence rather than the 'big picture'. In the Aboriginal Tent Embassy, the reverse is true the ephemerality of the architecture is of 'fundamental' importance. The Tent Embassy's appearance of ephemerality allowed its twenty-eight year tradition to be initiated by stealth. Whereas a permanent building might have been illegal under building by-laws, camping on the site in ACT in 1972 was not technically illegal. The camp allowed the Embassy six months of publicity before an ordinance could be gazetted and invoked. Only then did police demolish the Embassy in the "most violent demonstrations Canberra had ever seen'.$^{23}$ This ephemeral architecture did not fade away, but subsequently came back into life. Because of its ephemerality, the camp needs periodic renewal by activists who 'inhabit' the Embassy structure. Ephemeral architecture can moreover be considered environmentally responsible development, erected 'just in time', lasting only as long as needed, and often designed to be salvaged for re-use or to biologically degrade into the bush once abandoned.

Pragmatism is another name for the ironic practice of the Tent Embassy, from its earliest stages as a beach umbrella to its form as a more complex collection of tents, tarpaulins and domestic effects. The visibility of domestic 'reality' made the Tent Embassy more powerful. The social realism of 'cooking in the open and bed linen spread out to dry' was reported as 'bringing the reality of Aboriginal Australia right to Australia's front door'. ${ }^{24}$ Instances of cooking in the open and the spreading out of bed linen to dry clearly have resonances with the early accommodations of the first fleet. The unintentional similarity draws attention to the double standard of indigenous and exotic modes of inhabitation.

Why are Western theories of architectural hierarchies not helpful in understanding the Aboriginal Tent Embassy? The theoretical roots of the Embassy are rhizomatic, rather than arboreal, as Western theories are structured. ${ }^{25}$ The Aboriginal Embassy sprang from an impromptu idea, it 'start(ed) as a joke'26 conceived in collaboration between seven men discussing the content of the planned Australia Day speech of Prime Minister McMahon. The Embassy came about with the loan of a car and a $\$ 70$ grant from the Communist Party, enabling four activists to travel from Sydney to Canberra. Initially, a beach umbrella was erected, soon to be followed by a 'sprinkling' 27 of tents. Regularity was not introduced and confusion did not give place to system, as it had in 1788 . Western notions of architectural planning and construction cannot therefore be readily applied to this incidental form of architecture. The colonial 'settler' culture, over the last two centuries, has applied Western theory with limited success to pragmatic traditions of 'settling' the Australian continent. At the same time, theory and intellectuals have only succeeded in holding tentative positions in Australian cultural identity whether because of the cultural tension of apprehension towards an uncanny land, ${ }^{28}$ or as David Malouf has suggested in his 1998 Boyer lectures, because of a latent desire to play. ${ }^{29}$ 
Architecture as a Western concept has roots in material craft traditions developed in ancient European society. An enormous divide exists between craft and dwelling practices of the ancient world behind modern Western architecture and the nomadic dwelling traditions of ancient Australia. This cultural divide is graphically manifest in the architecture of the Aboriginal Tent Embassy. These 'informal' dwellings are culturally significant for architectural thinking; they are expressions of human inhabitation which are of equal social significance to sanctioned institutions. The informal and nomadic are critical to the process of discovering what architecture means for Australia today. The Aboriginal Tent Embassy is also a practical and potent 'occupation' of Australian space; physical, social and political.

Intemational attention was drawn to the Australian government when it brutally mistreated the peaceful protesters at the Tent Embassy in July 1972. The police 'manhandled' and assaulted the structure of the camp and molested the protesters. The protesters had peacefully demonstrated at Australia's democratically appointed forum. One MP called this one of the oldest principles of British law: to respect the democratic right of all Australians to assemble peaceably to demonstrate political points of view, in a manner of their own choice, and without limit of duration. ${ }^{30}$ The principle of unlimited ephemeral occupation has become a critical feature of the encampment. The grounds of Parliament, in the nation's Capital Territory, constituted a symbolically laden space on manicured lawn.

Despite its ostensibly uncertain future, physically ephemeral, yet culturally institutionalised by the National Heritage Register, the Embassy embodies and accommodates Aboriginal activism by example, thus engendering and accommodating activism for the rights of indigenous people. Like the fringe dweller camps of rural Australian towns with which its appearance has been compared, ${ }^{31}$ the Aboriginal Tent Embassy is a makeshift camp. It is comprised of materially indeterminate architecture, which challenges the idea of architecture as an agency of civilisation and peaceful settlement in Australia. ${ }^{32}$ The Aboriginal Tent Embassy buildings nevertheless represent a subversive architecture of protest having a deep-rooted significance for architecture in Australia. Importantly, the camp is more than shelter; it embodies not only needs but culturally significant desires. More than rudimentary primitive shelter, the Embassy is a collapsible symbolic monument.

Since 1992, the Aboriginal Tent Embassy has been continuously occupied, although its exact location has varied somewhat. In 1995 the Aboriginal Tent Embassy was registered by the Australian Heritage Commission on the National Estate, as the first Australian Aboriginal Heritage Site. The Embassy was recorded as a 'heritage place' which is nationally recognised for the political struggle of the Aboriginal people. The Aboriginal Tent Embassy pitched camp in a gesture intended undoubtedly to confront the provisional Parliament House in a media-savvy and graphic demonstration. At the same time, the Tent Embassy affronted many people in the way that it appropriated the language of camping and the great Australian Outdoors. It constituted a radical use of 'ready-mades' such as the beach umbrella and after-market contemporary tents combined with the improvised shelters of tarpaulins. Rather than a presenting a romanticised impression of nomadic life 'out bush', the Embassy was actually an embarrassing reflection of the realistic contemporary dwelling conditions found in many fringe dweller camps in rural towns around the nation. 
The Tent Embassy is particularly powerful because its architectural expression confronts the basic cultural assumptions of the imposed European culture and its expectations of 'proper' architectural expression. The Aboriginal Tent Embassy is a threatening 'nomadic institution', a self-contradiction - which is architecturally challenging in four main ways. Firstly, the Embassy is an impermanent structure juxtaposed against its context; secondly, the Tent Embassy implies, for some, the threat of militant invasion of the parliamentary circle (evidenced by the bringing of a newly gazetted 1932 trespass ordinance in 1972 to enable the police to remove the protesters legally); thirdly, the Tent Embassy's continual resurrection is a strategy for the maintenance of a culture - the Tent Embassy's (physical) architecture is short-lived, requiring movement; finally, the Tent Embassy is strategically sited. The careful urban planning order which distances each international embassy from the federal Parliament is violated with the placement of the tents on the 'front lawn'. The lawn at provisional Parliament House is the equivalent to the 'front lawn' of the colonial suburban house type, a type which is at the heart of the great majority of Australian suburbanites.

As an ingenious architectural device of stealth, the Embassy, it seems, evades the oppression often acted by the establishment through parking violations, building by-laws, town planning applications, or signage by-laws.

\section{Reconciling Architecture}

Symbolically or theoretically interpreting the twenty-eight-year tradition of the Aboriginal Tent Embassy and its historical resonances provides an opportunity for working on the architectural reconciliation of nomadic and settled elements of society in Australia today. The Tent Embassy's spontaneous and patchy physical architecture of lightweight, colourful, and impermanent materials and its mockthreatening location in front of 'Old Parliament House' make the Embassy an ironically fitting pilgrimage destination. Besides its role as a media focus for land rights and reconciliation processes, the site is legitimately part of Australia's national heritage, acting as the setting for memorial services for activists in $1993,{ }^{33}$ and for a wedding in $1997 .{ }^{34}$

The unapologetic and unsympathetic architecture of the federal government's Provisional Parliament House is effectively foiled by the strategically placed 'fringedwellers camp'. Although critics have called attention to its outward appearance as 'ramshackle'35 and an 'eyesore', ${ }^{36}$ the Tent Embassy offers more than a superficial aesthetic. The ephemeral folds and spaces of the Aboriginal Tent Embassy provide a useful and critical aesthetic contrast with the massive and monolithic white architecture of a colonial bureaucracy. ${ }^{37}$ The incidental construction of the Aboriginal Tent Embassy represents the positive nomadic qualities of a portable Australian architecture.

A reading of the Aboriginal Tent Embassy carries the message that the time has come for an engagement of indigenous race relations in Australia with cross-cultural thinking about architecture. The architectural manifestation of the land rights activism of the early 1970 s is continuing in the twenty first century. This challenge is posed as a strategy for approaching issues of reconciliation between Australian people and also with the environment.

Notes on pages $210-211$ 